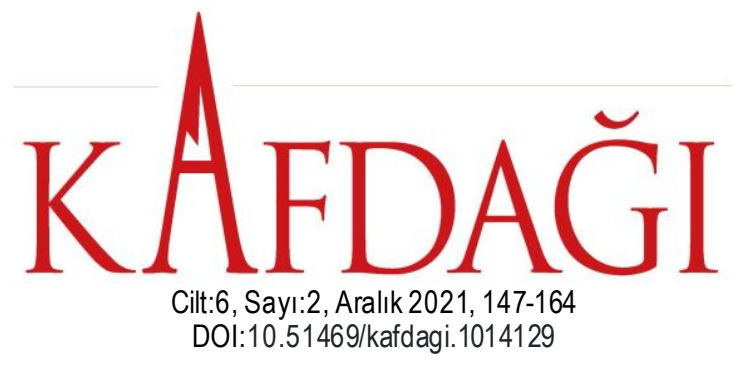

Gönderim Tarihi: 24.10 .2021

Kabul Tarihi:15.12.2021

\title{
MİLLİ MÜCADELE DÖNEMİ TÜRK EĞITTIM TARİHİ (1920-1923)
}

Turkish Educatıonal History In The Natıonal Struggle Perıod (1920-1923)

\section{Ahmet KUŞCi}

Dr., Hatay Mustafa kemal Üniversitesi

Fen Edebiyat Fakültesi Tarih Bölümü

kusciahmet78@gmail.com

\section{ORCID ID: 0000-0001-7168-6466}

$\ddot{O} z$ Çalışmanın Türü: Araştırma

Ölüm kalım mücadelesinin verildiği 1920-1923 yllları arası dönemde elbette ki eğitim ön planda tutulamazdl. Buna ră̆men Mustafa Kemal, eğitim-öğretin faaliyetlerini bizzat takip etmiş, ulusal ve çağdaş bir eğitim modeli oluşturmaya çalışmıştır. Bu çalışmanın amacı, erken cumhuriyet dönemi olarak kabul edilen 1920-1923 yılları arası Milli Ë̆itimin teşkilatlanma sürecini, Türk eğitim sisteminin genel yapısını ve Milli Ĕ̈itim Bakanları'nın çalışmalarını sistemli ve bütünsel bir biçimde ortaya koymaktır. Bu çalışma 1920-1923 arası uygulanan eğitim politikaları ve faaliyetlerinin ortaya konması açısından önem taşımaktadır.

Bu çalıșmada nitel araștırma yöntemlerinden biri olan betimsel tarama kullanılmıștır. Verilerin analizinde ise doküman analizi tekniği kullanılmıştır. Bu çalı̧̧mada başta Arşiv Belgeleri ve TВMM Zabut Cerideleri olmak üzere telif ve tetkik eserlerden istifade edilmiştir. Çalışma sonucunda 1920-1923 yılları arası dönemde dört Maarif Vekilininin görev yaptı̆̆ belirlenmiştir. Dört Maarif Vekili Döneminde de eğitim ile ilgili çalıșmalar yapılmış ve ögretmen sorunlarıyla ilgilenilmiştir. Ayrıca 1920-1923 yılları arasında Maarif Vekaleti'nin kurulmasl, Maarif kongresinin toplanmasl, Misak-ı Maarif'in yayımlanması ve Birinci Heyet-i Illmiyye'nin toplanması gibi ĕgitim alanında önemli faaliyetler gerçekleşmiştir. Bu faaliyetlerin cumhuriyetin ilanından sonra gerçekleşen eğitim ile ilgili yeniliklerin temelini oluşturduğu görülmektedir.

Anahtar Kelimeler: Erken Cumhuriyet Dönemi, Heyet-i Ilmiyye, Maarif Kongresi, Milli Mücadele

\section{Abstract}

Of course, education could not be prioritized in the period between 1920 and 1923, when the struggle for life and death was fought. Despite this, Mustafa Kemal personally followed the education-teaching activities and tried to create a national and contemporary 
education system. The aim of this study is to reveal the organizational process of the National Education between the years 1920-1923, which is accepted as the early republican period, the general structure of the Turkish education system and the work of the Ministers of National Education in a systematic and holistic manner. This study is important in terms of revealing the educational policies and activities implemented between 1920-1923.

In this study, descriptive survey, one of the qualitative research methods, was used. In the analysis of the data, the document analysis technique was used. In this study, primarily the Turkish Grand National Assembly's Minutes, copyright and examination works were used. As a result of the study, it was determined that four Ministers of National Education served in the period between 1920-1923. In addition, important activities in the field of education such as the establishment of the Ministry of Education, the convening of the Maarif congress, the publication of the Misak-ı Maarif and the gathering of the First Committee of Education between the years 1920-1923. It is seen that these activities formed the basis of the innovations related to education that took place after the proclamation of the republic.. Keywords: Early Republican Period, Heyet-i Ilmiyye, Education Congress, National Struggle.

\section{Giriş}

1920-1923 yılları arasını kapsayan ve büyük bir kısmı savaşla geçen bu dönem, eğitim konusunun ciddi bir şekilde ele alındığı "Cumhuriyet Eğitimine Hazırlık Dönemi" olarak kabul edilmektedir. 1920'li y1llarda Millî eğitim ideolojisi, emperyalizme karşı verilen Kurtuluş Savaşı, Büyük Millet Meclisinin kurulması, Saltanatın kaldırılması, Cumhuriyetin ilanı, Halk Fırkasının ülkede tek parti yönetimini kurması gibi önemli olayların olduğu tartışmalı bir dönemde kurulmuştur (Duman, 1991, s. 25; Kaplan, 1999, s. 133).

İcra Vekilleri Heyeti kurulduktan sonra Maarif Vekilliğine Rıza Nur seçilmiştir. Rıza Nur göreve başladıktan sonra ilk iş olarak İcra Vekilleri Heyeti tarafından belirlenecek programa eğitimle ilgili sorunları ekletebilmek için, Ankara Millî Eğitim Müdürlügü’'nden gelen bir me murla çalışarak yeni kurulan hükümetin eğitim misyonunu belirlemiştir. Eğitimin Millî ve dini olması, ders kitaplarının Millî kültür ve geleneklere uygun olması, okulların bilimsel ve çağdaş imkanlara sahip olması, yayımlanacak edebi ve tarihi eserler ile sözlüklerin Millî duygularla geliştirilmesi, Batı'nın ve Doğu'nun bilimsel kaynaklarının Türkçeye çevrilmesi ve okulları en iyi şekilde yönetilmesi, yeni kurulan hükümetin eğitim ilkeleri olarak belirlenmiştir (Sakaoğlu, 1993, s. 15).

9 Mayıs 1920 tarihinde kurulan İcra Vekilleri Heyetinin Büyük Millet Meclisinde okunan Bakanlar Kurulu programında Maarif Vekili Dr. Riza Nur bu konuşmasında eğitimle ilgili amaçları şu şekilde sıralamıştır: 
$\checkmark$ Eğitimi Millî ve dini bir hale getirmek.

$\checkmark$ Eğitimi; öğrencileri başarılı kılacak, üretici bir kişi haline getirecek yüksek bir seviyeye ulaştırmak.

$\checkmark$ Okulları ve öğretim programlarını bilimsel ve çağdaş temellerle yeniden düzenlemek.

$\checkmark$ Türk milletinin doğasına uygun, iklim ve coğrafi şartlara ve toplumsal ve tarihi geleneklere özgü olarak hazırlanmış ilmi ders kitapları oluşturmak.

$\checkmark$ Türk dilinin sözlüğünü yapmak.

$\checkmark$ Millî ruhu geliştirecek tarihsel, toplumsal ve edebi eserleri bu konuda uzman olan kişilere yazdırmak.

$\checkmark$ Tarihi eserleri korumak

$\checkmark$ Doğunun ve Batı'nın bilimsel kitaplarını dilimize çevirmek

$\checkmark$ Millî eğitim faaliyetlerine dikkat etmek ve bu faaliyetlerde özenle çalışmak.

$\checkmark$ Okulları iyi yönetmek (TBMM Zabıt Ceridesi, 9 Mayıs 1920, s. 241-242).

Görüldügü gibi yeni Türk devletinin ilk resmi programı Millî ve dini bir eğitim ile birlikte hayatta başarı sağlayacak bir öğretimi birleştirme amacı taşımaktadır (İnan, 1975, s. 152; Kaplan, 1999, s. 153).

\section{Millî Mücadele Dönemi Millî Eğitim Bakanları}

23 Nisan 1920'de açılan TBMM, 11 vekaletten oluşan ilk hükümetini 2 Mayıs 1920'de oluşturmuştur. Oluşturulan bu hükümette Maarif Vekaletine Rıza Nur seçilmiştir. Millî Mücadele Dönemi'nde Rıza Nur'un Maarif Vekilliğinden sonra sirasıyla Hamdullah Suphi, Mehmet Vehbi ve İsmail Safa Bey Maarif Vekaletine Vekillik yapmışlardır.

1920 yılında Maarif Vekâleti;

$\checkmark \quad$ Program Kurulu

$\checkmark \quad$ İlköğretim Müdürlüğü

$\checkmark \quad$ Ortaöğretim Müdürlügü

$\checkmark \quad$ Türk Asârı Atikası Müdürlüğü

$\checkmark \quad$ Sicil İstatistik Müdürlüğü olmak üzere 5 bölümden oluşmuştur (Sarı, 2014, s. 169; Türk ve Kılıç, 2015, s. 2).

\subsection{Rıza Nur (4 Mayıs 1920-13 Aralık 1920)}

Sekiz ay on bir gün maarif vekilliği yapan Riza Nur Sinop'ta doğmuştur. Askeri tıbbiyeden doktor yüzbaşı olarak çıktıktan sonra tıp fakültesinde öğretmenlik yapmıştır. 1908 yılında milletvekili s eçilen Rıza 
Nur, 1924 yılında siyasetten ayrılarak edebiyat ve tarih çalıșmalarına başlamıştır. BMM kurulduktan sonra, Maarif Vekaleti kurulup, BMM'nin ilk Maarif Vekilliğine Rıza Nur seçilmiştir. Böylece İstanbul'da Maarif-i Umumiyye Nezareti ve Ankara'da Maarif Vekaleti olmak üzere faaliyetlerini aynı anda sürdüren iki tane eğitim bakanlığı kurulmuş oldu. Rıza Nur, Aralık 1920'de Maarif Vekilliğinden ayrılmıştır. Sıhhat ve Muaveneti İçtimaiye Vekili iken özel görev için Ukrayna'ya gidecek heyetin içinde yer alma sın a rağmen bu görevinden de istifa etmiştir (TBMM Gizli Celse Zabıtları, 25 Nisan 1922). Daha sonra Mısır'a geçerek 5 yıl İskenderiye'de kalmıştır. Türk Birliği Revüsü ve Tanrı Dağı dergilerini çıkaran Rıza Nur'un ölümünden sonra yayımlanan "Hayat ve Hatıralarım" adında bir de kitabı bulunmaktadır. Rıza Nur, 8 Eylül 1942 tarihinde İstanbul' da v efat etmiştir (Yazıc1, 1973, s. 118; Sertkaya, 2004, s. 64; Önder, 2012, s. 188).

Rıza Nur, Maarif Vekilliği döneminde ortaöğretim kurumlarının ihtiyaçlarının devlet bütç esinden karşılanması için sekiz maddelik bir kanun tasarısı hazırlayıp meclise sunmuştur. Bizzat kendisi tarafından okunan bu kanun tasarısı meclis tarafından kabul edilmemiștir (TBMM Zabıt Ceridesi, 17 Temmuz 1920, s. 319). Rıza Nur, Maarif Vekilliği dönemin de e ğitimin millî olması konusunda önemle durmuştur. Bu amaçla atasözleri, halk türküleri, sporlar, millî oyunlar ve şiirlerin toplanması için çalışmalar yaptırmıştır. Ayrıca yazışmalarda Türkçe sözcüklerin kullanılmasını istemiş ve bu amaçla Türk Dili Sözlüğü hazırlanması için çalışma başlatmıştır. Ülkenin içinde bulunduğu savaş şartlarından dolayı eğitim ile ilgili ön emli faaliyetlerin yaşanmadığı bu dönemde, en önemli icraatın Maarif Vekâleti'nin kuruluşu olduğu görülmektedir (Başar, 1988, s. 72-73).

\subsection{Hamdullah Suphi Tanrı̈ver (14 Aralık 1920-20 Kasım 1921)}

On bir ay sekiz gün Millî Eğitim Bakanlığı yapan Hamdullah Suphi 1885 yılında İstanbul'da doğmuştur. Galatasaray Lisesini bitirdikten son ra İstanbul Erkek Öğretmen Okulu'nda öğretmenlik yapmıştır. Büyük Millet Meclisi açıldıktan sonra Saruhan milletvekili olarak seçilmiştir. Rıza Nur'un bakanlığından sonra 6 Aralık 1920 tarihinde Millî Eğitim Bakanlığı seçimine gidilmiştir. Hamdullah Suphi, Maarif Vekilliğine aday olarak gösterilen Zekâi Bey (Adana), Vehbi Bey (Karesi) ile girdiği seçimde 66 oy alarak Maarif Vekili olmuştur. Hamdullah Suphi, Maarif Vekilliğinden sonra Bükreş'e giderek 1932 yılından 1944 yılına kadar elçilik ya pmıştır. 1945 yılında CHP'den İstanbul milletvekili seçilen Hamdullah Suphi, CHP'nin yedinci büyük kongresinde kendisine yöneltilen eleştirilerden dolayı partisinden istifa etmiştir. 1950 seçimlerinde DP'den İstan bul milletvekili seçilen Hamdullah Suphi, 1957 yılında DP'den de istifa ederek Hürriyet 
Partisine geçmiştir. Hamdullah Suphi 10 Haziran 1966 tarihinde vefat etmiştir (Yazıcı, 1973, s. 118-119; Başar, 1988, s. 75-77; Sarı, 2014, s. 175).

Hamdullah Suphi, Maarif Vekili olduktan sonra savaş şartlarından dolayı ödenemeyen öğretmen maaşları için devlet bütçesinden 110 bin liralik ödeneğin Maarif Vekaleti bütçesine eklenmesini sağlamıştır. Millî bir eğitim politikası izleyen Hamdullah Suphi, zararlı ve yıkıcı faaliy etlerde bulunan Antalya çevresindeki azınlık okullarını kapatmıştır. Hamdullah Suphi, Maarif Vekilliği döneminde ilköğretim ve ortaöğretim ilgili bir yasa tasarıs1 hazırlamıştır. Bu yasa tasarısına göre, ilköğretim 6 yıldan 4 yıla indirilecek, ortaögretim de 4 yıl olacak ve bunun ilk 3 yılında genel eğitim 4 . yılında ise mesleki eğitim verilecekti. Ancak bu yasa tasarısı meclis tarafından kabul edilmemiştir (Başar, 1988, s. 88-89).

\subsection{Mehmet Vehbi Bolak (20 Kasım 1921-5 Kasım 1922)}

On bir ay, on altı gün Maarif Vekilliği yapan Mehmet Vehbi, 1882 yılında Balıkesir'de doğmuştur. İlk ve orta öğrenimini Balıkesir'de, liseyi ise Bursa'da tamamlamıştır. Mehmet Vehbi, Karesi bölgesinden milletvekili seçilip Büyük Millet Meclisine girmiştir. Hamdullah Suphi'nin 12 Kasım 1921 tarihinde görevinden ayrılmasından sonra, Karesi Milletvekili Mehmet Vehbi (Bolak), meclisten aldığı 105 oy ile Maarif Vekilliğine atanmıştır. Millî Eğitim Bakanlığı'ndan sonra Balıkesir'e dönen Mehmet Vehbi, 6 Nisan 1948 tarihinde vefat etmiştir (Sertkaya, 2004, s. 151; Sarı, 2014, s. 179).

Mehmet Vehbi Maarif Vekili olduktan sonra, öğretmenlerin maaşlarını vaktinde almasını sağlamak, ilköğretim ve ortaöğretim kurumlarının kapanmasını önlemek ve öğretmen ve ögrencilerin askerlikten tecilleri hakkındaki kanunun uygulanmasını sağlamak gibi sorunlarla uğraşmıştır. Dini bir eğitim politikası izleyen Mehmet Vehbi, okulların programını hazırlama görevini çoğunluğu din adamlarından oluşan bir komisyona vermiştir. Bu komisyonun aldığı kararlar eğitim camiasında ve basında geniş yankı uyandırınca uygulamaya konmamıştır (Başar, 1988 , s. 101-102). Mehmet Vehbi'nin Maarif Vekilliği döneminde, Avrupa'ya eğitim amacıyla gönderilen öğrencilerin masraflarını karşılamak maksadıyla Maarif bütçesine ek ödenek konulması meclise sunulmuştur (BCA, 30/18/1/1 5/16/3, 8 May1s 1922).

\section{4. İsmail Safa Özler (5 Kasım 1922-27 Ekim 1923)}

Bir y1l dört ay iki gün Maarif Vekilliği yapan İsmail Safa, 1885 yılında Adana'da doğmuştur. Mersin milletvekili olarak meclise giren İsmail 
Safa, 5 Kasım 1922 tarihinde Maarif Vekilliğine seçilmiştir. Maarif Vekilliği sırasında Sıhhiye Vekilliğine de geçici olarak vekalet etmiştir (BCA, 30/18/1/1-6/41/7). İsmail Safa 28 Haziran 1940 tarihinde vefat etmiştir. İsmail Safa Bey döneminde eğitim yemini olarak kabul edilen Misak-1 Maarif hazırlanmıştır. Misak-1 Maarif ile yeni Türk devletinin eğitim alanında ulaşmak istediği hedefler belirtilmiştir. Ayrıca İsmail Safa Bey, Mekatib-i Hususiye Talimatnamesinin altıncı maddesinde değişiklik yapmıştır. Yapılan bu değişiklikle yabancı dilde öğretim yapan özel okullarda Türk öğretmenler tarafından Türkçe, Tarih ve Coğrafya gibi derslerin Türkçe okutulması karar altına alınmıştır (Önder, 2012, s. 192).

\section{Millî Mücadele Dönemi Eğitim Faaliyetleri}

\subsection{Nolu Kanun (2 Mayıs 1920)}

2 Mayıs 1920 tarihli ve 3 sayılı yasa ile Fevzi Çakmak başkanlığında İcra Vekilleri Heyeti kuruldu. Maarif Vekaleti (Millî Eğitim Bakanlığı) de İcra Vekilleri Heyetine bağlı olarak oluşturulan 11 bakanlıktan biri olarak kuruldu. Büyük Millet Meclisinde Fevzi Çakmak başkanlığında kurulan ilk İcra Vekilleri Heyetinde Maarif Vekili olarak Dr. Rıza Nur görev yaptı (Ceyhan, 2004, s. 55).

Maarif Vekaleti hizmet açısından şu bölümlere ayrılmıştır.

$\checkmark$ Yedi üyeden oluşan bir ders programı heyeti

$\checkmark$ Müdür ve iki kâtipten oluşan İlköğretim müdürlüğü

$\checkmark$ Müdür ve iki kâtipten oluşan Ortaöğretim müdürlüğü

$\checkmark$ Müdür ve bir kâtipten oluşan Türk asari atikası (Eski Eserler) müdürlüğü

$\checkmark$ Müdür ve bir kâtipten oluşan İstatistik müdürlüğü

$\checkmark$ Üç müfettiş (Ayasbeyoğlu, 1948, s. 122-23).

\subsection{Maarif Kongresi (16-21 Temmuz 1921)}

16-21 Temmuz 1921 tarihinde yani millî mücadelenin devam ettiği yıllarda Ankara'da Maârif Kongresi'nin toplanması, Mustafa Kemal'in eğitim ordusuna olan inanç ve güveninin en büyük işareti olmuştur. Türkiye Muallime ve Muallimler Birliği'nin düzenlediği ve Anadolu'nun farklı yerlerinden gelen 220'den fazla kadın ve erkek öğretmenin katıldığı bu kongrede alınan kararlarla Cumhuriyet sonrası eğitim alanında yapılacak olan inkılapların temelleri atılmıştır. 16 Temmuz 1921 tarihinde Ankara'd a toplanan Maarif Kongresi, Türk eğitim tarihinin ilk eğitim kurultayı ola rak kabul edilmektedir (Demirtaş, 2008, s. 158; Sarıhan, 2013, s. 312).

Mustafa Kemal 16-21 Temmuz 1921 tarihinde gerçekleşen Maarif 
Kongresinin açıș konușmasında maarif kongresini "Millî Türkiye'nin "Maarif Ë̆itimi'ni" kuracak olan Türkiye Muallime ve Muallimler Kongresi" şeklinde tanımlamıştır. Konuşmasında yıllardır uygulanan ihmaller sonucunda devlet kurumlarında ortaya çıkan sorunların ancak eğitim ile giderilebileceğinden bahseden Mustafa Kemal, Millî bir eğitim programı hazırlanması gereğinden de bahsetmiş̧ir. Mustafa Kemal konuşmasında, eğitimin verimli ve etkili olabilmesi için uygulanan eğitim yöntem ve tekniklerinin değiştirilmesi gerektiğini ve ders kitaplarının hurafelerden arındırılarak Millî tarihimize ve benliğimize uygun hale getirilmesi gerektiğini belirtmiştir. Konuşmasında, velilerin ve öğretmenlerin çocukların eğitimi için her türlü fedakârlığı yapması gerektiğini belirten Mustafa Kemal, öğretmenlerin refah seviyesi ve yaşam kalitesinin arttırılmasından da bahsetmiştir (Türk Devrim Tarihi Enstitüsü Yayımları-6, 1946, s. 3-5; Sakaoğlu, 2003, s. 161, Akyüz, 1983, s. 91-92).

Türk eğitim tarihinin bir miladı olarak kabul edilen Maarif Kongresi'nin açış konuşmasında Mustafa Kemal, Millî eğitim ve kültürün önemini, eğitim yöntemleri ile ilgili reform yapılması gerektiğini ve yapılacak bu reformların esaslarını, öğretmenlik mesleğinin ku tsiyetini ve ögretmenlerin sorumluluklarını anlatan önemli bir konuşma yapmıştır. Mustafa Kemal kongredeki bu konuşması ile kurulacak olan yeni Türk devletinin eğitim prensiplerini belirleyerek Türk halkına güven vermiştir (Akyüz, 1983, s. 100).

\subsubsection{Toplantının Amacı ve Üyeleri}

16-21 Temmuz 1921 tarihleri arasinda Ankara'da toplanan Maarif Kongresi'nin Türk eğitim tarihi içinde önemli bir yeri vardır. Bu kongrenin toplanma amacı, mevcut okul, öğretmen ve öğrenci sayısını tespit etmek, bu konuda yapılması gereken faaliyetleri belirlemek ve eğitimin millîleştirilmesini sağlamaktır. Maarif Kongresi ile birlikte Türk eğitim sisteminde, eğitim teşkilatı ve müfredat programlarında yenilik çalışmaları başlamıştır. Hükümet programında yer alan ve yapılması önc elikle gerekli işler üzerinde çalışmalar sürdürülürken Türk eğitim sisteminde örgütlen me, eğitim kurumları ve programında reform yapılması için ilk planlama yapılmasına girişilmiştir (Kapluhan, 2016, s. 123).

16 Temmuz 1921 tarihinde toplanan Maarif Kongresi'nin gündeminde yer alan konular şunlardır:

$\checkmark$ İstatistiki bilgiler

$\checkmark$ Okulların sayısı ve derecesi, okul binaları

$\checkmark$ Öğretmenlerin sayısı ve derecesi 
$\checkmark$ Öğrencilerin sayısı ve derecesi

$\checkmark$ Öğrenci velilerinin mesleği

$\checkmark$ Kiz okullarının sayısı ve derecesi

sağlanacak istifade

$\checkmark$ Meşrutiyetten kalma okulların durumu ve Vekaletçe bun lardan

$\checkmark \quad$ Mahalli eğitimin gelişmesi için düşünülen durum 129).

$\checkmark$ Son beş sene içinde eğitime ayrilan bütçe (Kapluhan, 2014, s.

Maarif Kongresi toplantısı Maarif Vekili Hamdullah Suphi Bey'in Başkanlığında Dârül Muallimîn binasındaki konferans salonunda yapılmıştır. Kongreye ülkenin her tarafindan 250'den fazla kadın ve erkek ö ğretmen katılmıştır. Zor şartlar altında toplanan kongrenin üyelerine yirmi bin lira bütçe ayrılmıştır. $\mathrm{Bu}$ durum mecliste tartışmalara neden olmuş, Batum Milletvekili Fevzi Bey yaptığı konuşmada milletin parasının boşuna harcandığını belirtmiştir. Bu eleştirilere cevap veren Maarif Vekili Hamdullah Suphi Bey, dünyadaki bütün medeni milletlerin kendi kongrelerini topladığını belirtmiştir (TBMM Zabıt Ceridesi, 10 Kasım 1921 , s. 168-170). Yol ve konaklama masraflarının delegeler tarafından karşılandığı kongrede, yemek masraflarından ise tasarruf edilmiştir (Akyüz, 2007, s. 320; Gül, 2018, s. 518).

Ankara'da Maarif Kongresi toplanmadan önce 1 Ocak 1921'de kongreye;

$\checkmark$ Elyevm bilfiil muallim olanlar (Görevde olan öğretmenler)

$\checkmark$ Maarifmüdürleri (Millî eğitim müdürleri)

$\checkmark$ Mektep müdürleri (Okul müdürleri)

$\checkmark$ Telif ve Tercüme Heyeti azalarl (Telif ve tercüme heyeti üyeleri) müdürleri)

$\checkmark$ Maarif Vekaleti daire müdürleri (Millî Eğitim Bakanlığı şube ögretmenleri)

$\checkmark$ Ali dersler ve konferanslar müderrisleri (Yükseköğretim

$\checkmark$ Her gazete namina bir mümessil olmak şartıla gazete mümessilleri davet edilmiştir. ( Her gazeteden birer temsilci) (Bozkurt, 2007, s. 22-23).

\subsubsection{Toplantıda Alınan Kararlar ve Toplantının Değerlendirilmesi}

Maarif kongresinde alınan kararlar:

Maarif Vekaleti'nce hazırlanan halk mektepleri ile ilgili bir proje taslağı üzerinde durulmuştur. Bu proje taslağında, öğrencilerin toplumsal 
yaşamdaki çalışma hayatına yönelik bilgi ve becerilerinin artması için yeni bir programın uygulanması lazım olduğu belirtilmiş ve zorunlu ilköğretimin 4 yıldan 5 yıla çıkarılması teklif edilmiştir.

Köylüler 6 yıl olan İptidai okullarının öğrenim süresini fazla bu lduğu için ve bu okullarda okutulan birçok dersin gereksiz olduğunu düşünerek kendi başlarına mahalle mektepleri açmıştır. Bundan dolayı eğitimi y aymak için okullarda üst düzey programlar değil, köylünün ihtiyaç duyduğu ve istediği dersler doğrultusunda ilköğretim programı hazırlayıp ve bu doğrultudaki derslerin okutulması gerektiği belirtilmiştir.

Kongrede ayrıca kız okullarının ders programlarına, kızların ev yaşamında ihtiyacı olabilecek gerekli pratik uygulamaların konulması gerektiği belirtilmiştir. Ayrıca iptidai okullarının ders programlarına tüm meslek derslerinin konulmasının zor olacağı, ancak her türlü iş ve sanat için yetenek hazırlamanın mümkün olabileceği belirtilmiştir (Akyüz, 1983, s. 9697; Sakaoğlu, 2003, s. 161-162; Kapluhan, 2014, s. 129).

On iki gün sürmesi planlanan Maarif Kongresi, İstiklal Savaşı'nın tüm şiddetiyle devam etmesinden dolayı daha kısa sürede tamamlanmıştır. Bundan dolayı kongre üyeleri, ilköğretime ve ortaöğretime ait bazı kararlar dışında gündem maddelerinde yer alan konuların tümünü inceleyememiştir. Maarif Kongresi devam ederken Kütahya-Eskişehir muharebeleri b aşla dı ğ1 için kongre sonuçlandırılamadan dağılmak zorunda kalmıştır (Akyüz, 1983, s. 100; Bozkurt, 2007, s. 26).

İstiklal Savaşı'nın en zorlu günlerinde Ankara'da öğretmenlerin eğitim için toplanması, Türk eğitim tarihinin mihenk taşlarından biri olarak kabul edilen Maarif Kongresi'nin önemini daha da arttırmıştır. Yunan saldırılarının en ateşli zamanında Mustafa Kemal'in cepheden gelerek eğitim ile meşgul olmas1, dünya tarihinde eşi benzeri görülmeyen bir örnek olarak karşımıza çıkmaktadır (Akyüz, 1983, s. 101).

\subsection{Maarif Misakı (Ĕ̈̆itim Andl-8 Mart1923)}

17 Şubat 1923 tarihinde toplanan İzmir İktisat Kongresi’nin Türk eğitim tarihi içinde pek bilinmeyen ama önemli bir yeri bulunmaktadır. İzmir İktisat Kongresi'nin Türk eğitim tarihine katkısı, eğitim ile ekonomi arasındaki ilişkinin ilk kez resmi olarak bir kurulda belirtilmiş olmasıdır. İzmir İktisat Kongresi'nde bir konuşma yapan Mustafa Kemal konuşmasında hem ilköğretim hem de ortaöğretimin ders programlarının -öğrencilerin tarım ve ticarette faydalı olabilmesi için- ekonomi programı ile uyumlu olması gerektiğini belirtmiştir. Bu kongreden yola çıkarak Maarif Vekili 
İsmail Safa (Özler), 8 Mart 1923 tarihinde, "Misak-1 Maarif” adıyla Türk eğitim sisteminin genel amaçlarını bir genelge hâlinde düzenlemiş ve bu genelgeyi tüm okullara göndermiştir. Bu genelgeye göre eğitimin amac1, Millî ve çağdaş eğitimi yurdun her köşesine ulaştırmaktır. Genelgede, eğitim kurumlarından beklenenler, eğitim ve öğretimin amaçları, 1923 yılında uygulanacak program, ögretmen okulu bölgeleri, ortaöğretim programları, ögretmenlerin refah seviyesinin arttırılması, okullar ve dil dersleri ve telif ve tercüme konuları üzerinde durulmuştur (Özalp ve Ataünal, 1983, s. 112; Binbaş1oğlu, 1995, s. 177; Binbaş1oğlu, 1999, s. 176; Gündüz, 2018, s. 125). 1923)

2.4. Birinci Heyet-i İlmiye Toplantısı (15 Temmuz-15 Ağ ustos

\subsubsection{Toplantının Amacı ve Üyeleri}

15 Temmuz 1923'te Ankara'da Türk Ocağı'nda toplanan Birinci Heyet-i İlmiye, eğitim sorunlarının bütün yönleriyle ele alındığı, Türk eğitim tarihinin ilk sistemli ve reformist çalışması kabul edilmekted ir. Toplanma amac1, Türk eğitim sisteminin sorunlarını belirlemek ve dönemin uzman eğitimcilerinin tecrübelerinden faydalanarak bu sorunlara çözüm yolları bulmak ve yapılan değerlendirmeleri bir karara bağlamaktır (Özalp ve Ataünal, 1983, s. 109; Tanır ve Aslan, 2019, s. 251).

Tablo 1 Birinci Heyeti İlmiyye Toplantısına Katılan Üyeler

\begin{tabular}{lll}
\hline $\begin{array}{l}\text { Sira } \\
\text { No }\end{array}$ & Adı & Görevi \\
\hline 1 & Samih Rifat Bey & Müsteşar \\
2 & Ziya Gökalp Bey & Telif ve Tercüme Heyeti Başkanı \\
3 & Veled Çelebi Bey & Telif ve Tercüme Heyeti Üyesi \\
4 & Mustafa Rahmi Bey & Telif ve Tercüme Heyeti Üyesi \\
5 & Şefik Bey & Yüksek Öğretim Müdürü \\
6 & Nafi Atuğ Bey & Ortaöğretim Müdürü \\
7 & Refet Bey & Ilköğretim Müdürü \\
8 & Abdülfeyyaz Tevfik Bey & Teftiş Heyeti Müdürü \\
9 & Hilmi Bey & Müfettiş \\
10 & Mübarek Bey & Kültür Müdürü \\
\hline
\end{tabular}




\begin{tabular}{|c|c|c|}
\hline 11 & Avni Bey & İstatistik Müdürü \\
\hline 12 & Köprülüzade Fuad Bey & Darülfünun Edebiyat Medresesi \\
\hline 13 & Mustafa Zühtü Bey & Darülfünun Hukuk Medresesi \\
\hline 14 & Hüsnü Hamit Bey & Fen Fakültesi Öğretmeni \\
\hline 15 & Dr. Vasfi Bey & Darülfünun Tıp Medresesi \\
\hline 16 & Cemil (Cem) Bey & Güzel Sanatlar Müdürü \\
\hline 17 & Vehbi Bey & Serbest Âli Dersleri Müderrisi \\
\hline 18 & İhsan Bey & $\begin{array}{l}\text { İstanbul Darülmuallimini } \quad \hat{A} \text { liye } \\
\text { Müdürü }\end{array}$ \\
\hline 19 & Ali Haydar Bey & $\begin{array}{l}\text { Darülmuallimatı Âliyeden; Terbiye } \\
\text { Muallimi }\end{array}$ \\
\hline 20 & Faik Bey & Galatasaray Okul Müdürü \\
\hline 21 & Hasan Fehmi Bey & Kabataş Lisesi Matematik Öğretmeni \\
\hline 22 & Ali Rıza Bey & Kastamonu Lisesi Edebiyat Öğretmeni \\
\hline 23 & Hulusi Bey & Antalya Dârülmuallimin Müdürü \\
\hline 24 & Recep Nuri Bey & İstanbul Lisesi İptidai Başöğretmeni \\
\hline 25 & Ahmet Edip Bey & İlk Tedrisat Eski Müdürü \\
\hline 26 & Sirrı Bey & $\begin{array}{l}\text { Darülmuallimini Âliye Beden Eğitimi } \\
\text { Öğrt. }\end{array}$ \\
\hline 27 & Ali Sami Bey & Sporcu \\
\hline 28 & Necmettin Sadık Bey & Sosyoloji Öğretmeni \\
\hline 29 & Celal Esad Bey & Gazi Köy Belediye Müdürü \\
\hline 30 & Şekip Bey & Psikoloji Öğretmeni \\
\hline 31 & İsmail Hakkı Bey & Terbiye Müdürü \\
\hline 32 & Naci Paşa & Müdafaa-i Millîye Vekâleti \\
\hline 33 & Abdülmuttalip Bey & İçişleri Bakanlığı Nüfus Müdürü \\
\hline 34 & Hamdi Bey & $\begin{array}{l}\text { Şer'iyye ve Evkaf Vekâleti Tedris } \\
\text { Müdürü }\end{array}$ \\
\hline
\end{tabular}




\begin{tabular}{lll}
\hline 35 & Âkil Bey & $\begin{array}{l}\text { Bayındırlık } \\
\text { Mühendisi }\end{array}$ \\
36 & Dr. Ziya Bey & Sağlık ve Sosyal Yardım Bakanlığı \\
37 & Cemal Hüsnü Bey & Ekonomi Bakanlığı İstatistik Müdürü \\
38 & Ağaoğlu Ahmed Bey & Basın-Yayın Genel Müdürü \\
39 & Yakup Kadri Bey & Yazar \\
40 & İzzet Ulvi Bey & Afyonkarahisar Milletvekili \\
41 & İzci Büyük Ortası & Bir Üye \\
\hline
\end{tabular}

Kaynak: Yücel, 1994, s. 21; Bozkurt, 2020, s. 1751).

Tablo 1'de görüldüğü gibi Birinci Heyet-i İlmiyye toplantısına 1 müsteşar, 11 bürokrat, 15 müdür, 12 öğretmen, 1 milletvekili, 1 sporcu olmak üzere toplam 41 kişi katılmıştır. Maarif Vekaleti tarafından Birinci Heyet-i İlmiyye toplanmadan önce 11 Temmuz 1923 tarihinde 11 kişilik Heyet-i İlmiyye üyelerinin masraflarını karşılamak üzere 1.200 liranın harcanması için bir genelge çıkarılmıştır (BCA, 30/1/1/1-7/24/16).

Birinci Heyet-i İlmiyye 15 Temmuz- 15 Ağustos 1923 tarihleri arasında İsmail Safa Bey'in Millî Eğitim Bakanlığı döneminde Ankara'da toplanmıştır. Türk Eğitim tarihinin ilk sistemli çalışması olarak kabul edilen birinci Heyet-i İlmîye; bakanın başkanlığında, müsteşar, bakanlık genel müdürleri, ilgili bakanlıkların temsilcileri, üniversite profesörleri, yüksekokul müdürleri, çeşitli tür ve derecedeki eğitim kurumlarının temsilcilerinin katılımlarıyla toplanmıştır.

\subsubsection{Toplantıda Alınan Kararlar ve Toplantının Değerlendirilmesi}

Birinci Heyet-i İlmiye toplantısının Millî eğitim teşkilatının altyapısını oluşturması bakımından öncü bir rol oynadığı kabul edilmektedir. Birinci Heyet-i İlmiye kararlarının yeni kurulan Türk Devleti tarafınd an kısmen uygulandığı görülmektedir. Ülkenin içinde bulunduğu durum ve Heyeti ilmiye kararlarının tavsiye niteliğinde olması bunda etkili olmuştur (Tanır ve Aslan, 2019, s. 268).

Tablo 2 Birinci Heyet-i İlmiyye Toplantısı Gündem Maddeleri

\begin{tabular}{llc}
\hline $\begin{array}{l}\text { Sira } \\
\text { No }\end{array}$ & Konu & Bölüm \\
1 & Millî Hars & Milli \\
\hline
\end{tabular}




\begin{tabular}{|c|c|c|}
\hline 2 & Millî Tarih ve Coğrafya Enstitüleri & Milli \\
\hline 3 & Millî Hazine Evrakı & Milli \\
\hline 4 & Millî Dil ve Edebiyat & Milli \\
\hline 5 & Millî Büyük Sözlük & Milli \\
\hline 6 & Millî Tarih Kitaplı̆̆g & Milli \\
\hline 7 & Millî Müzik & Milli \\
\hline 8 & Etnografya Müzesi & Milli \\
\hline 9 & Okul Müzesi & Milli \\
\hline 10 & Millî Müze & Milli \\
\hline 11 & $\begin{array}{l}\text { Üstün Değerde Müracaat Kitaplarının Dilimize } \\
\text { Çevrilmesinde Takip Olunacak Esaslar }\end{array}$ & İdari \\
\hline 12 & $\begin{array}{l}\text { İstanbul Kız ve Erkek Öğretmen Okullarında Orta Kısım } \\
\text { Açılması }\end{array}$ & İdari \\
\hline 13 & Galatasaray Lisesinin Teşkilat ve Programları & İdari \\
\hline 14 & $\begin{array}{l}\text { Sultanîlerde Teşkilat ve Öğretim Süresi ve Sultanî adının } \\
\text { Değiştirilmesi }\end{array}$ & İdari \\
\hline 15 & Lise İzcilik Esas Teşkilatı & İdari \\
\hline 16 & Teftiş Kurulu Tüzük Teklifi & İdari \\
\hline 17 & Eski Eserler Tüzüğü & İdari \\
\hline 18 & $\begin{array}{l}\text { Yüksek Öğretmen Okulu Öğrencilerine Mesleki Bilgiler } \\
\text { Verilmesi }\end{array}$ & İdari \\
\hline 19 & Millî Eğitim Yürütme Programı & İdari \\
\hline 20 & Kız ve Erkek Öğretmen Okulları Tüzük ve Programları & İdari \\
\hline 21 & İlkokul Programlarında Değişiklikler, & İdari \\
\hline 22 & İlköğretimden Sonra Hayatî Öğretim Programı, & İdari \\
\hline 23 & İlköğretim Kararnamesinin Değiştirilmesi Teklifi & İdari \\
\hline 24 & İstatistik Genel Müdürlüğü Teşkilatı & İdari \\
\hline 25 & Ankara'da Yüksek Seviyede Dersler & İdari \\
\hline
\end{tabular}




26 Din Eğitimi Esasları Dini

Kaynak: Sakaoğlu, 1993, s. 19.

Tablo 2'de görüldüğü gibi Birinci Heyet-i İlmiyye toplantısının gündemi 26 maddeden oluşmuştur. Bu gündem maddelerinin on beşi id ari, onu milli ve biri de dini konu alt başlıklarını içermektedir. Birinci Heyet-i İlmiye toplantısında oluşturulan komisyonlar, gündem maddelerinde yer alan konuları 1 ay boyunca incelemiştir. Bu incelemelerden sonra ortaya çıkan değerlendirmeler bir rapor haline getirilip genel kurula sunulmuştur. Birinci Heyet-i İlmiye toplantısında alınan kararlar:

$\checkmark$ Zorunlu eğitim 7-14 yaşları arasını kapsamaktadır.

$\checkmark$ İlköğretimin süresi 6 yıldır ancak liseye gidemeyecekler için zorunlu eğitimden 2 yıl daha faydalanmalarına izin verilmiştir.

$\checkmark$ Belirli yerlerde yatılı bölge okulları kurulacaktır.

$\checkmark$ Öğretmenlerin 1 defaya mahsus askerlik tecil etme hakları bulunmaktadır.

$\checkmark$ Millî Eğitim Bakanlığı dışındaki diğer bakanlıkların ilköğretim okulu açma izni bulunmamaktadır.

$\checkmark$ "Sultani" adının "Lise" olarak değiştirilmesine karar verilmiştir. (Önder, 2011, s. 193).

Birinci Heyeti İlmiye kararları cumhuriyet ilan edilmeden önceki 14 Ağustos 1923 tarihinde Meclis'te okunan hükümet programına esin kayn ağ1 olmuştur. Hükümet programında çocukların eğitimi, ilköğretimde mesleki yönlendirme, kızlar için lise ve öğretmen okullarının çoğaltılması, ilköğretimin zorunlu hale getirilmesinin yer alması programda eğitime u zun bir bölüm ayrıldığı görülmektedir. Cumhuriyetin ilk yıllarındaki eğitim uygulamalarına rehberlik eden Birinci Heyeti İlmiye kararları daha sonra yapılacak olan Maarif Şuralarının da başlangıcı olarak kabul edilmekted ir (Sakaoğlu, 1993, s. 19; Önder, 2011, s. 192; Gündüz, 2018, s. 126).

\section{Millî Mücadele Dönemi Eğitim Kurumları}

XIX. yüzyılın ortalarından itibaren Osmanlı eğitim politikasında görülen batı tarzı modem eğitim, mahalli mektepler dışında halk tarafın dan kabul görmemiştir. Temel amac1, Kur'an ve din bilgisi ile birlik te okuma yazma öğretmek olan Sıbyan Mektepleri Osmanlıdaki ilköğretim seviyesindeki okullardır. Bu okullara halk dilinde mahalle mektebi ya da Taş Mektep de denilmektedir.1913'te Tedrisat-1 İptidaiye Kanun-1 Muvakkati (İlköğretim Geçici Yasası) kabul edilmiştir. Bu yasa ile ilköğretim kurumlarında değişiklikler yapılmış; zorunlu ilköğretim süresi 6 yıl olarak düzenlenmiştir (Budak ve Budak, 2014, s. 53; Çağır ve Türk: 2017, s. 63). 
Millî Mücadele Dönemi'nde Anadolu'daki eğitim istatistikleri istenilen düzeyde değildi. Bu dönemde Ankara Hükümeti’ne bağlı 38 il ve sancakta 581'i kapalı olmak üzere toplam 2.345 ilkokul bulunmaktayd1. $\mathrm{Bu}$ okullardaki ögretmen sayısı 2.384'ü erkek, 677 'si kadın olmak üzere toplam 3.061 'idi. Bu ögretmenlerden sadece 875 'i ögretmen okulu mezunuydu. Ortaögretimde ise ortalama olarak 60 idadi, 28 sultani ve 18 öğretmen okulu bulunmaktaydı. Millî Mücadele Dönemi’nde Anadolu'daki köylerin \%98'i okulsuz durumdaydı (Soydan, 2013, s. 62).

19 Ekim 1920 tarihindeki Büyük Millet Meclisinin 86. toplantı 2. oturumunda Maarif Vekili Dr. Rıza Nur eğitim kurumlarının sayıları ile ilgili şu bilgileri vermiştir: 28 Sultani (Lise) bulunmaktadır. 340 Yatılı öğrenci, 2591 gündüzlü öğrenci bulunmaktadır. Öğretmen ve memurların sayısı 587'dir. 50-60 arası İdadi (ortaokul) bulunmaktadır. İlk okulların ise en az 40.000 ögretmene ihtiyac1 olduğunu belirtmektedir (İnan, 1975, s. 154).

İsmail Hakkı Tonguç ve Faik Reşit Unat'ın 1929'da yayımladıkları Muallim Yıllığı isimli kitapta 10 Mayıs 1920 tarihinde Türkiye'nin okullaşma durumu şöyle gösterilmiştir: 682'si kapalı olmak üzere 3495 İlkokul, 3316 İlkokul öğretmeni, 5 tam devreli 12 yıllık sultani, 32 sultani ve idadi (9 yıllık), 13 Öğretmen okulu, 4 kız öğretmen okulu Maarif vekaletinin 1923 yılında yayımladığı bir rapora göre düşman işgalinde bulunmayan yerlerde ortaöğretim okullarından 4 'ü yatılı, 17 'si yatısız olmak üzere toplam 21 Sultani ve tamamı yatısız olan 3 idadi bulunmaktaydı. Ortaögretim Genel Müdürlüğü personel sayısı 1920 yılında 1 genel müdür 1 mümeyyiz ve 2 kâtip olmak üzere 4 kişiden oluşmaktaydı. 1921 yılında 1 genel müdür 1 mümeyyiz ve 2 kâtip olmak üzere 4 kişiden oluşmaktaydı. 1922 yılında da 1 Genel müdür 1 Mümeyyiz ve 2 kâtip olmak üzere 4 kişid en oluşmaktaydı (İnan, 1975, s. 160; Yücel, 1994, s. 21-40).

Millî Mücadele Dönemi'nde savaş şartlarından dolayı eğitime ayrılan bütçe de kısıtlı olmuştur. Hatta Aydın Milletvekili Tahsin Bey mecliste yaptığı konuşmasında eskiden beri eğitimde geri kalınmışlıktan şikâyet edilmesine rağmen yine de en az bütçenin eğitime ayrıldığını belirtmiş̧ir (TBMM Zabıt Ceridesi, 10 Şubat 1921, s. 166). 1921 yılında devlet bütç esi 57.128.833 lira iken eğitime ayrılan bütçe 390.412 lira olmuştur. 1922 y1lında devlet bütçesi 74.957.848 lira iken eğitime ayrlan bütçe 1.136.064 lira olmuştur. 1923 yılında ise devlet bütçesi 105.929,911 lira iken eğitime ayrılan bütçe 3.033, 003 lira olmuştur (Başgöz ve Wilson, 1968, s. 97-98; İnan, 1983, s. 6). 


\section{Sonuç}

Millî Mücadele yıllarında milli bağımsızlık kadar eğitime de önem verilmiş ve bu doğrultuda birçok çalışma yapılmıştır. Bu çalışmalardan ilki Maarif Vekaleti'nin kurulmasıdır. Maarif Vekaleti, kurulduktan sonra hem eğitim işleriyle hem de öğretmenlerin maaşlarını alamaması gibi kronik sorunlarla da uğraşmıştır. 1920-1923 yılları arasında dört Maarif Vekili görev yapmıştır. İlk Maarif Vekili olan Rıza Nur'dan sonra Hamdullah Suphi (Tanrı̈ver), Mehmet Vehbi (Bolak) ve İsmail Safa (Özler) görev yapmıştır. Millî mücadele döneminde eğitim alanındaki en köklü çalışmaların İsmail Safa Bey'in döneminde yapıldığı görülmektedir. Bunun nedeni ise Kurtuluş Savaşı'nın başarıyla sonuçlanması neticesinde Maarif Vekaleti' nin bütün gücünü eğitime vermiş olmasıdır.

Millî mücadele yıllarında eğitim alanında gerçekleşen önemli gelişmelerden biri de Maarif Kongresi'nin toplanmasıdır. Mustafa Kemal bu kongrede ilk defa milli eğitimin tanımını yaparak milli eğitimin kuruluş sürecini başlatmıştır. Ayrıca bu dönemde adı konmamış yeni devletin milli eğitim politikasını belirlemek için uzmanlardan oluşan Birinci Heyet-i İlmiyye toplantısı yapılmıştır. Millî mücadele yıllarında eğitim ile ilgili kurulan teşkilatlar ve yapılan reformlar incelendiğinde, benimsetilmeye çalışılan eğitim felsefesinin yeni ulus devlet yapısı doğrultusunda bir eğitim anlayışı benimsetilmeye çalışıldığı görülmektedir.

\section{KAYNAKLAR}

Akyüz, Y. (2007). Türk Ĕgitim Tarihi M.Ö 1000-MS 2007. Ankara: Pegem A Yayıncilık.

Ayasbeyoğlu, N. (1948). Türkiye Cumhuriyeti Millî Eğitimi Kuruluşlar ve Tarihçiler. Ankara: Millî Eğitim Basımevi.

Başar, E (1988). Cumhuriyet Dönemi Milli Eğitim Bakanları ve Ícraatlarının Değerlendirilmesi (1920-1960) (Yayımlanmış Doktora Tezi). Ankara Üniversitesi, Ankara.

Başgöz, İ., \& Wilson, H. E. (1968). Türkiye Cumhuriyeti’nde Eğitim ve Atatürk. Ankara: Dost Yayınları.

$B C A$, 30/18/1/1-5/16/3, 8 May1s 1922 .

$B C A, 30 / 18 / 1 / 1-6 / 41 / 7,16$ Aralik 1922 .

BCA, 30/1/1/1-7/24/16, 11 Temmuz 1923.

Binbaşığlu, C. (1995). Öğretmen Yetiştirme Açısından Türkiye'de Eğitim Bilimleri Tarihi Üzerinde Bir Araştırma. İstanbul: M.E.B.

Binbaşığlu, C. (1999). Cumhuriyet Dönemi Ĕ̆itim Bilimleri Tarihi. Ankara: Tekışık.

Bozkurt, B. (2007). Cumhuriyet Halk Partisinin Ĕ̆itim Politikaları (1923-1950) 
(Yayınlanmamış Doktora Tezi). Dokuz Eylül Üniversitesi, İzmir.

Bozkurt, B. (2020). Cumhuriyet Türkiyesinin Eğitim Sisteminin İnşası Sürecin de Heyeti İlmiye Toplantıları. Belgi Dergisi. (19), 1748-1765.

Budak, L., \& Budak, Ç. (2014). Osmanlı İmparatorluğu'ndan Türkiye Cumhuriyeti'ne İlkokul Programlan (1870-1936). Türkiye Sosyal Araştırmalar Dergisi, 18(1), 51-68.

Ceyhan,E. (2004). Türk Eğitim Tarihi Kronolojisi, 1299-1997. Edirne: Ulusal.

Çağır, M., \& Türk, İ. C. (2017). 1869 Maarif-i Umumiye Nizamnamesi ve Türk Eğitim Tarihindeki Yeri. Avrasya Sosyal ve Ekonomi Araştırmaları Dergisi, $4(11), 37-50$.

Demirtaş, B. (2008). Atatürk Döneminde Eğitim Alanında Yaşanan Gelişmeler. Gazi AkademikBakış, 1(2), 155-176.

Duman, T. (1991). Türkiye'de Ortaöğretime Öğretmen Yetiştirme. İstanbul: MEB.

Gül, O. K. (2018). Maarif Kongresi, Heyet-i İlmiyeler ve Uluslararas1 Ortaöğretim Öğretmenleri Kongresi Üzerine Bir Değerlendirme. Karadeniz Sosyal Bilimler Dergisi, 10(19), 509-523.

Gündüz, M. (Ed.) (2018). Kronolojik ve Tematik Türk Eğitim Tarihi. İstanbul: İdeal Kültür Yayınc1lı.

İnan, M.R. (1975). Atatürk'ün Devraldı̆̆ E Ĕitim, Öğretim Durumu ve Kurumlarl (Eğitim Düzeni). Ankara: Türk Tarih Kurumu Basımevi.

İnan, M.R. (1983). Atatürk'ün Evrenselliği, Önder Kişiliği, Eğitimci Kişiliği ve Amaçları. Ankara: TİSA Matbaası.

Kaplan, I. (1999). Türkiye'de Millî Ĕ̆itim İdeolojisi ve Siyasal Toplumsallaşma Üzerindeki Etkisi. İstanbul: İletişim.

Kapluhan, E. (2016). Hazırlık (Kurtuluş Savaşı) Dönemi Eğitim Politikaları ve Eğitim Faaliyetleri. Mehmet Akif Ersoy Üniversitesi Eğitim Bilimleri Enstitüsü Dergisi, 1(1), 1-28.

Neziroğlu, İ., \& Yılmaz, T. (2013). Hükümetler, Programlarl ve Genel Kurul Görüşmeleri: (24 Nisan 1920 - 22 Mayıs 1950). Ankara: TBMM Basımevi.

Önder, M. (2011). Türk Ĕ̈itim Tarihi. Erzincan: Sözkesen Matbaac1lık.

Özalp, R. ve Ataünal, A. (1983). Milli Eğitimde Kongreler ve Şuralar, Cumhuriyet Döneminde Eğitim (ss. 105-141). İstanbulMillî Eğitim Basımevi.

Sakaoğlu, N. (1993). Cumhuriyet Dönemi Eğitim Tarihi (2. Basım). İstanbul: İletişim Yayınları.

Sarı, M. (2014). Yeni Türk Devletinin İlk Maarif Vekâleti (Kuruluşu ve Çalışmaları 1920-1923). Atatürk Yolu Dergisi, 14(54), 169-194.

Sarıhan,Z. (2013). Millî Mücadelede Maarif Ordusu. İstanbul: Tarihçi Kitabevi.

Sertkaya, A. (2004). I. Meclis Dönemindeki Eğitim ve Kültür Faaliyetleri ve Millî Ĕ̆itim Bakanları, (Yayınlanmamış Yüksek Lisans Tezi). Gazi Üniversitesi, Ankara.

Soydan, T. (2013). Osmanlı'dan Cumhuriyet Dönemine Türkiye'de Temel Eğitimin Gelişmesi ve Finansmanı Sorunu. Karadeniz Sosyal Bilimler Dergisi, 5(8), 53-71.

Tanır, E. D., \& Aslan, C. (2019). Birinci Heyet-i İlmiye ve Çalıșma Esasları. Ankara 
Universitesi Egitim Bilimleri Fakultesi Dergisi, 52(1), 251-276.

TBMM Gizli Celse Zabıtları, 25 Nisan 1922, C.3, İçtima: 34.

TBMM Zabit Ceridesi, 17 Temmuz 1920, C. 1, İçtima: 36.

TBMM Zabıt Ceridesi, 9 Mayıs 1920, C. 1, İçtima: 13.

TBMM Zabıt Ceridesi, 10 Şubat 1921, C. 1, İçtima: 148.

TBMM Zabıt Ceridesi, 10 Kasım 1921, C. 3, İçtima: 108.

Türk Devrim Tarihi Enstitüsü Yayımları-6 (1946). Cumhurbaşkanları, Başbakanlar ve Millî Eğitim Bakanlarının Millî Eğitim ile Ilgili Söylev ve Demeçleri. Ankara: Millî Eğitim Basımevi.

Türk, E., \& Kılıç, A. F. (Eds.) (2015). Türk Eğitim Sistemi ve Ortä̈ğretim. Ankara: Ortaöğretim Genel Müdürlügü.

Yazıc1, M. (1973). Tanzimattan Bu Yana Millî Eğitim Bakanlarl Başbakanlar ve Atatürk 1839-1973. Ankara: Emel Matbaacilik.

Yücel, H.-A. (1994). Turkiye'de Ortaögretim. Ankara: T.C Kültür Bakanlığı Millî Kütüphane Basimevi. 